\title{
Risk-Based management of contaminated groundwater: The role of geologic heterogeneity, exposure and cancer risk in determining the performance of aquifer remediation
}

\author{
R. M. Maxwell, S. F. Carle and A. F. B. Tompson
}

This article was submitted to

U.S. Department of Energy

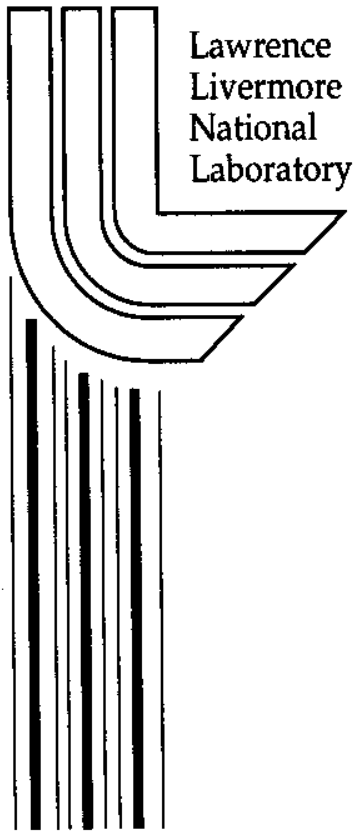

American Society of Civil Engineers, 2000 Joint Conference on Water Reources Engineering and Planning and Management, Minneapolis, MN, July 30 - August 2, 2000

\section{April 7, 2000}




\section{DISCLAIMER}

This document was prepared as an account of work sponsored by an agency of the United States Government. Neither the United States Government nor the University of California nor any of their employees, makes any warranty, express or implied, or assumes any legal liability or responsibility for the accuracy, completeness, or usefulness of any information, apparatus, product, or process disclosed, or represents that its use would not infringe privately owned rights. Reference herein to any specific commercial product, process, or service by trade name, trademark, manufacturer, or otherwise, does not necessarily constitute or imply its endorsement, recommendation, or favoring by the United States Government or the University of California. The views and opinions of authors expressed herein do not necessarily state or reflect those of the United States Government or the University of California, and shall not be used for advertising or product endorsement purposes.

This is a preprint of a paper intended for publication in a journal or proceedings. Since changes may be made before publication, this preprint is made available with the understanding that it will not be cited or reproduced without the permission of the author.

This report has been reproduced directly from the best available copy.

Available to DOE and DOE contractors from the Office of Scientific and Technical Information

P.O. Box 62, Oak Ridge, TN 37831

Prices available from (423) 576-8401 http://apollo.osti.gov/bridge/

Available to the public from the National Technical Information Service

U.S. Department of Commerce 5285 Port Royal Rd., Springfield, VA 22161 http://www.ntis.gov/

OR

Lawrence Livermore National Laboratory Technical Information Department's Digital Library http://www.llnl.gov/tid/Library.html 
Risk-Based management of contaminated groundwater: The role of geologic heterogeneity, exposure and cancer risk in determining the performance of aquifer remediation

R.M. Maxwell (1,2), S.F. Carle (1) and A.F.B. Tompson (1)

(1) Geosciences and Environmental Technologies Division, Lawrence Livermore National Laboratory (L-204), Livermore, CA 94551 USA

(2) Associate Member, ASCE; PH 925-422-7426, email: maxwell5@llnl.gov

ABSTRACT: The effectiveness of aquifer remediation is typically expressed in terms of a reduction in contaminant concentrations relative to a regulated maximum contaminant level (MCL), and is usually confirmed by sparse monitoring data and/or simple model calculations. Here, the effectiveness of remediation is examined from a risk-based perspective that goes beyond the traditional MCL concept. A methodology is employed to evaluate the health risk to individuals exposed to contaminated household water that is produced from groundwater. This approach explicitly accounts for differences in risk arising from variability in individual physiology and water use, the uncertainty in estimating chemical carcinogenesis for different individuals, and the uncertainties and variability in contaminant concentPrations within groundwater. A hypothetical contamination scenario is developed as a case study in a saturated, alluvial aquifer underlying a real Superfund site. A baseline (unremediated) human exposure and health risk scenario, as induced by contaminated groundwater pumped from this site, is predicted and compared with a similar estimate based upon pump-and-treat exposure intervention. The predicted reduction in risk in the remediation scenario is not an equitable one - that is, it is not uniform to all individuals within a population and varies according to the level of uncertainty in prediction. The importance of understanding the detailed hydrogeologic connections that are established in the heterogeneous geologic regime between the contaminated source, municipal receptors, and remediation wells, and its relationship to this uncertainty is demonstrated. Using two alternative pumping rates, we develop cost-benefit curves based upon reduced exposure and risk to different individuals within the population, under the presence of uncertainty.

\section{INTRODUCTION}

Maximum Contaminant Levels (MCL's) are widely used to establish upper bound contaminant levels in groundwater that are considered safe to individuals who might use this water. Focusing aquifer remediation toward MCL-based targets is actually a form of risk-based management.

MCL's are risk-based numbers that are back-calculated from a simple exposure model contained within the United States Environmental Protection Agency's (USEPA) Risk Assessment Guidance for Superfund (RAGS; USEPA, 1989). A generic set of physiological and water usage assumptions is used to provide a conservative estimate of increased cancer risk to a Reasonable Maximally-Exposed Individual (RMEI). Based upon this, the increased cancer risk for this individual is then set to some de minimus value. The methodology used in RAGS (and therefore used to determine MCL's) removes varibility in individuals (e.g. individual water use and physiology) and the uncertainty (e.g. geologic heterogeneity) from the calculation of risk. It has been shown that such determinisitic methods for predicting human health risk provide much less 
fidelity than approaches that seek to propagate distributions of uncertainty and variability [e.g. $\mathrm{NRC}, 1994]$. This loss of resolution in prediction is particularly true when predicting risks from contaminated groundwater [Maxwell, et al, 1998], due to the complexities of geologic heterogeneity.

More sophisticated risk assessment methods are becoming increasingly popular in their application to contaminated groundwater [e.g. NRC, 1999; and Maxwell, Kastenberg and Rubin, 1999]. In this paper an alternate to the MCL approach will be presented. Here, site-specific parameters will be used to predict increased cancer risk to a distribution of consumers. This approach explicitly accounts for (i) the uncertainty and variability in the subsurface, as it affects groundwater flow and contaminant transport, and (ii) the variability in the physiology and wateruse behaviors of consumers who use this water for household purposes. Furthermore, the notion that a remediation strategy (in this case pump and treat) is an exposure intervention will be presented. In this way, remediation will be a means to reduce the concentration of contaminant at some down-gradient receptor (in this case a set of municipal water wells) thereby reducing human exposure and increased cancer risk. This reduction in risk will be evaluated and compared to the baseline risk of doing nothing at all. This reduction in risk is also subject to uncertainty and variability in subsurface geology. An ultimate outcome of this framework will be a risk-based cost-benefit analysis.

\section{RISK ASSESSMENT FRAMEWORK}

The risk analysis framework used in this paper, (Figure 1) links subsurface flow and transport, capture in downstream receptors (wells), delivery of this contaminant to different households within a region via a water distribution system (using a five year moving window of maximum concentration at the well), and human exposure in the household from three exposure pathways. These pathways include (i) direct ingestion (drinking), (ii) dermal contact (washing and bathing) and (iii) inhalation of volatilized contaminants due to showering. As used in a baseline sense, this framework is well described in previous work [Maxwell, et al., 1998; Maxwell and Kastenberg, 1999; and Maxwell, et al., 1999] and incorporates parameter uncertainty and/or variability in every parameter used in the assessment. Uncertainty is used to describe a lack of confidence in parameters that, in theory, tend to a single value. Uncertain parameters are treated as continuous distributions and are represented in the result as percentiles in uncertainty. Variability is used to describe parameters that vary spatially, temporally, or between individuals. Variable parameters are treated as discrete distributions of known quantities and are represented as fractiles in frequency. Incorporation of uncertainty and variability in the framework necessitates a nested, or two-dimensional, Monte Carlo procedure. The end result is a prediction of risk that is a two-dimensional variable, and is a function of uncertainty and variability.

\section{DESCRIPTION OF THE CASE STUDY}

The case studied in this paper is a hypothetical groundwater basin contaminated with an organic solvent. This geology and hydrology of the basin is based upon the Superfund site located at the Lawrence Livermore National Laboratory, in Livermore, California, USA. The location of the detailed study area is shown in Figure 2. The case study has two pumping wells used to provide municipal, household water to the residents who live there (referred to as the municipal pumping 
wells). Due to previous industrial practices, this aquifer is contaminated with tetrachloroethylene (PCE), which is introduced into the domain as a completely aqueous source. The location of the municipal wells and their extraction rate are hypothetical. A baseline risk assessment is evaluated, where no risk intervention is performed and the contamination is allowed to migrate downstream to the municipal wells where it is captured and delivered to the residents, and exposure occurs. A remediation well is located up-gradient from the municipal wells, and directly downgradient of the contaminant source. The location of the contaminant source and the location of the remediation well are idealized. A remediated risk is also evaluated, where the remediation well is used to intercept the contamination, and reduce exposure to the individuals who use this water for household uses. Figure 3 describes the site layout used for the case study.

The shallow aquifer system underlying LLNL consists of alluvial deposits of the Plio-Pleistocene Lower and Upper Livermore Formations [Carpenter et al., 1984]. It has been extensively characterized by geophysical logs, semi-continuous core, and lithologic descriptions from several hundred boreholes [Qualheim, 1988]. Four depositional facies - debris flow (7\%), flood plain $(56 \%)$, bar/levee (19\%), and channel (18\%) - are distinguished (with proportions given in percent) by textural analysis of core and facies model interpretation [Noyes, 1991]. Importantly, depositional facies have a geometric context in alluvial facies models [Walker, 1981] and, thus, form a scientifically defensible basis for building site-scale models of subsurface heterogeneity [Anderson, 1989; Anderson and Woessner, 1992, p. 29-37]. Well tests and core permeability measurements show that these depositional facies have distinctive hydraulic properties ranging over five orders of magnitude in hydraulic conductivity [Noyes, 1991; Fogg et al., 1998;

Tompson et al., 1999]. Site scale dispersion will be affected more by facies architecture than within-facies heterogeneity [Desbarats, 1990].

We employ an transition probability/Markov geostatistical approach to conditionally simulate the alluvial facies architecture [Carle et al., 1998]. Spatial variability is quantified by transition probability matrices as a function of lag [Carle and Fogg, 1996], the distance between two sampling points in a particular direction. The spatial variability is modeled by a threedimensional continuous-lag Markov chain, which closely fits transition probability data and is geologically interpretable [Carle and Fogg, 1997]. The conditional simulation algorithm employs a two-step procedure of sequential indicator simulation and simulated quenching [Carle, 1997]. The simulation algorithm accounts for variable dips and azimuths inferred from several distinct packages of alluvial sedimentation with different source regions, direction of progradation, and degrees of deformation [Blake et al., 1995]. Seven realizations were produced, each with cell size $3 \mathrm{~m}, 10 \mathrm{~m}, 0.3 \mathrm{~m}$ and dimensions of $1203 \mathrm{~m}, 2010 \mathrm{~m}, 144.9$ in the $\mathrm{x}, \mathrm{y}$, and $\mathrm{z}$ directions for a total of $38,930,283$ cells. The results of realization seven are shown in Figure 4.

For each of the realizations of hydraulic conductivity boundary conditions were imposed and the head potential was solved. The ParFlow flow code [Ashby and Falgout, 1996; Tompson et al., 1998] was used to solve the flow domain on the Accelerated Sciecntific Computing Initiative (ASCI) Blue-Pacific massively parallel computing facility at Lawrence Livermore National Laboratory. The problem flow domain was divided among 50 compute-nodes, totaling 200 processors. The flow problem was solved for three steady-state pumping scenarios: (i) a baseline case, with no remediation, where the two municipal wells are extracting 300 cubic meters of water per day, and (ii, iii) two remediated cases where the remediation well was extracting 140 and 210 cubic meters of water per day, respectively. The results of the baseline flow field for realization seven are shown in Figure 5. 
A Lagrangian particle-tracking code was used to simulate migration of PCE [Tompson et al., 1987; Maxwell, 1998; Maxwell and Kastenberg, 1999]. This code solves for advection, local scale dispersion, molecular diffusion, and simple, linear interactions between the contaminant and soil matrix that are dependent upon the local soil facies. A snapshot of the contaminant distribution after 15 years of migration is shown in Figure 6.

\section{RESULTS}

The concentration of contaminant in each of the downgradient wells for each realization, for both the remediated and baseline cases was calculated, and converted into a five-year maximum average concentration for use in the exposure calculations. Figure 7 shows the results of this calculation. For some realizations we see a significant decrease in the well concentration due to the remediation well, in other realizations we see either no-effect, or a slight increase in well concentration. This figure also shows a difference in the concentrations between wells for a given realization.

The five-year maximum average well concentrations may now be used to predict a human exposure to PCE via the three household exposure pathways noted earlier. This calculation was performed to 10,000 hypothetical individuals living within the basin, each with different, variable physiological and behavioral parameters. Figure 8 shows the results of this calculation, predicting the exposure to the median (or average) individual at the $50^{\text {th }}$ fractile, and an upper bound individual at the $95^{\text {th }}$ fractile in exposure. It may be noted that confidence in this prediction is represented by the cumulative distributions of uncertainty for each of the two representative individuals. The solid curves represent the baseline case, with the dashed curves representing the two remediated cases. It may be seen in this figure that the reduction in exposure is not uniform across the population, and is subject to uncertainty.

To further explore this uncertainty in exposure reduction, the percent reduction in exposure was calculated for each realization. The results of this calculation are shown in Figure 9 as a expected reduction in exposure to two different individuals within the population, one at the

median and one at the $95^{\text {th }}$ upper-bound, with the $10^{\text {th }}$ and $90^{\text {th }}$ confidence limits, as a function of pumping rate. In this figure it is shown that the expected value of exposure reduction increases as a function of the pumping rate. The uncertainty present in this prediction is significant, and it is shown that the reduction in exposure may be as great as $90 \%$, or as low as $-60 \%$.

\section{CONCLUSIONS}

We have presented a risk management methodology that goes beyond the concept of MCL's to evaluate the performance of remediation of contaminated aquifers. This methodology incorporates uncertainty and variability in model parameters to predict a baseline human health risk that is two-dimensional. Predictions of remediated human health risks based upon a pump and treat scenario with two extraction rates are used to evaluate the cost-benefit exposure intervention. This methodology, applied to a case study of an alluvial system underlying the LLNL Superfund site was used to show the importance of hydrogeologic connection in contaminant transport, exposure and exposure intervention. Figure 7 demonstrates intra and inter-realization differences in both the prediction of contaminant concentration under baseline and remediation scenarios. These insights stem directly from the incorporation of a more- 
sophisticated model of geologic subsurface heterogeneity. Figure 8 shows that remediation of a contaminant plume may result in different amounts of risk reduction to different members of the population. This raises questions regarding equity of risk-reduction among the poputhe uncertainties involved. Figure 9 suggests that the cost-risk-benefit of pump and treat might be positive (or even quantifiable) at the best scientific estimate. However, when the uncertainties involved are incorporated into the assessment, it becomes clear that the uncertainty in the prediction overwhelms the process. This would suggest that further understanding of interactions between remediation strategy and risk-reduction under conditions of uncertainty is warranted.

\section{ACKNOWLEDGEMENTS}

This work was funded by the Lawrence Livermore National Laboratory postdoctoral program. This work was conducted under the auspices of the U. S. Department of Energy by Lawrence Livermore National Laboratory, University of California under contract W-7405-Eng-48.

\section{REFERENCES}

Anderson, M.P. (1989) "Hydrogeologic facies models to delineate large-scale spatial trends in glacial and glaciofluvial sediments." Journal of Sedimentary Petrology. 40, 298-323.

Anderson M.P and W.W. Woessner (1992) Applied Groundwater Modeling. San Diego Academic Press, 391p.

Ashby, SF and R.D. Falgout (1996). "A parallel multigrid predconditioned conjugate gradient algorithm for groundwater flow simulations." Nuclear Science and Engineering, 124(1), 145159.

Carle S.F. and G.E. Fogg (1996) "Transition probability-based indicator geostatistics." Mathematical Geology, 28(4), 453-476.

Carle, SF. (1997) "Implementation schemes for avoiding artifact discontinuities in simulated annealing." Mathematical Geology, 29(2), 231-244.

Carle, SF and G.E. Fogg (1997) "Modeling spatial variability with one and multidimensional continuous-lag Markov chains." Mathematical Geology, 29(7), 891-918.

Carle, S.F., E.M. Labolle, G.S. Weissmann, D. Van Brocklin, and G.E. Fogg, (1998) "Conditional simulation of hydrofacies architecture: a transition probability/Markov approach." Hydrogeologic Models of Sedimentary Aquifers, Concepts in Hydrogeology and Environmental Geology No. 1, G. S. Fraser and J. M. Davis, eds, Society for Sedimentary Geology, Tulsa (SEPM), OK, 147-170.

Carpenter, D. W., P.W. Sweeney, P.W. Kasameyer, N.R. Burkhard, K.G. Knauss, and R.J. Shlemon (1984) Geology of the Lawrence Livermore National Laboratory Site and Adjacent Areas. Lawrence Livermore National Laboratory, Livermore, CA, (UCRL-53316).

Desbarats, A. (1990) "Macrodispersion in sand-shale sequences. "Water Resources Research, 26(1),153-163.

Fogg, G. E., C.D. Noyes, and S.F Carle (1998) "Geologically based model of heterogeneous hydraulic conductivity in an alluvial setting." Hydrogeology Journal, 6, 131-143.

Maxwell, R.M., S.D Pelmulder, A.F.B. Tompson, and W.E. Kastenberg (1998) "On the Development of a New Methodology for Groundwater-Driven Health Risk Assessment." Water Resources Research, 34(4), 833-847.

Maxwell, R.M. (1998) The Effects of Uncertainty and Variability in Groundwater-Driven Health Risk Assessment. Ph.D. Dissertation, University of California, Berkeley.

Maxwell, R.M., W.E. Kastenberg (1999) "Stochastic Environmental Risk Analysis: An Integrated Methodology for Predicting Cancer Risk from Contaminated Groundwater." Stochastic Environmental Research and Risk Assessment, 13(1-2), 27-47. 
Maxwell, R.M., W.E. Kastenberg, and Y. Rubin (1999) "A methodology to integrate site characterization information into groundwater-driven health risk assessment." Water Resources Research, 35(9), 2841-2856.

National Research Council (1994) Science and Judgement in Risk Assessment. National Academy Press, Washington, D.C., 651p.

National Research Council (1999) Environmental Cleanup at Navy Facilities: Risk-Based Methods. National Academy Press, Washington, D.C., 143p.

Qualheim, B. J. (1988) Well Log Report for the LLNL Ground Water Project 1984-1987. Lawrence Livermore National Laboratory, Livermore, California, UCID-21342.

Tompson, A.F.B., R.D. Falgout, S.G. Smith, W.J. Bosl and S.F. Ashby (1998) "Analysis of subsurface contaminant migration and remediation using high performance computing." Advances in Water Resources, 22(3), 203-221.

Tompson, A.F.B., E. G. Vomoris, and L.W. Gelhar (1987) Numerical simulation of solute transport in randomly heterogeneous porous media: Motivation, model development, and application. Lawrence Livermore National Laboratory, Livermore, CA, UCID-21281.

Walker, R. G. (ed) (1981) Facies Models. Geoscience Canada Reprint Series 1, Geoscience Canada, Toronto, $211 \mathrm{p}$.

Weissmann, G.S., S.F. Carle, and G.E. Fogg (1999) "Three dimensional hydrofacies modeling based on soil surveys and transition probability geostatistics." Water Resources Research, 35(6), 1761-1770.

US Environmental Protection Agency (1989) Risk Assessment Guidance for Superfund Volume I: Human Health Manual (Part A). Office of Emergency and Remedial Response, Washington D.C., EPA/540/1-89/002.

\section{FIGURES}

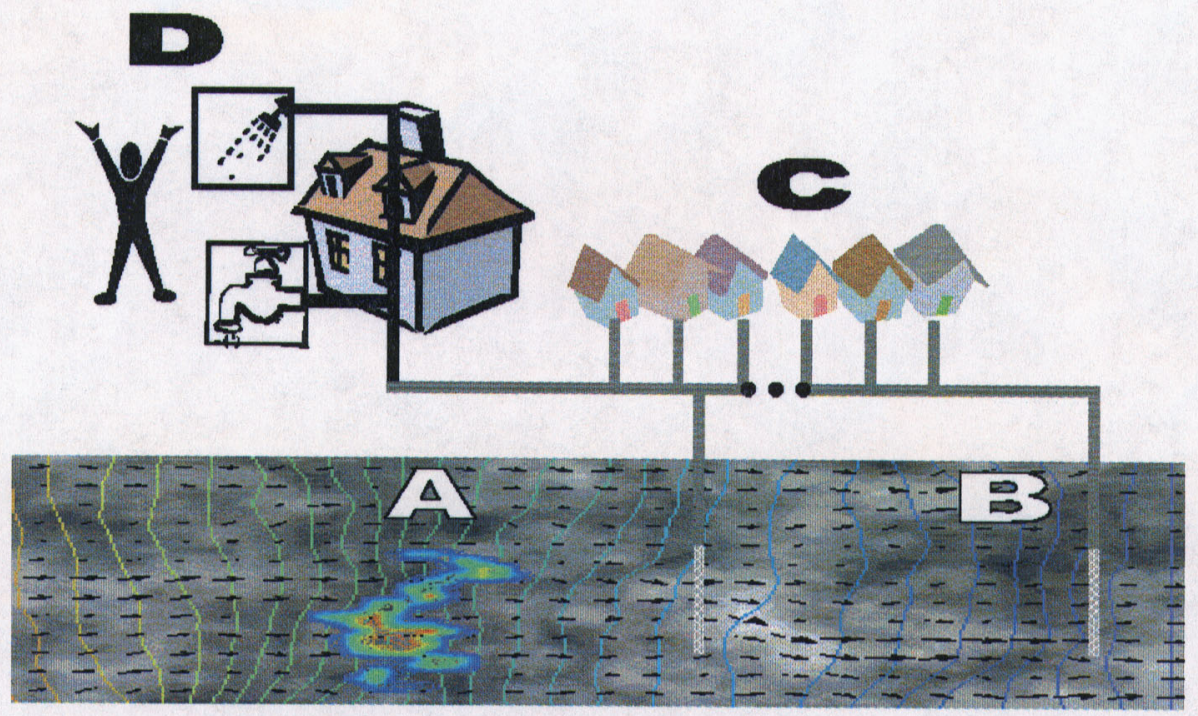

Figure 1. A depiction of the methodology used in this paper modified from Maxwell and Kastenberg (1999). It links: heterogeneous subsurface flow and transport (A); possible capture in one or more downgradient wells (B); water delivery system to households within the basin (C); and multipathway household exposure and health risk assessment to varying individuals (D). 


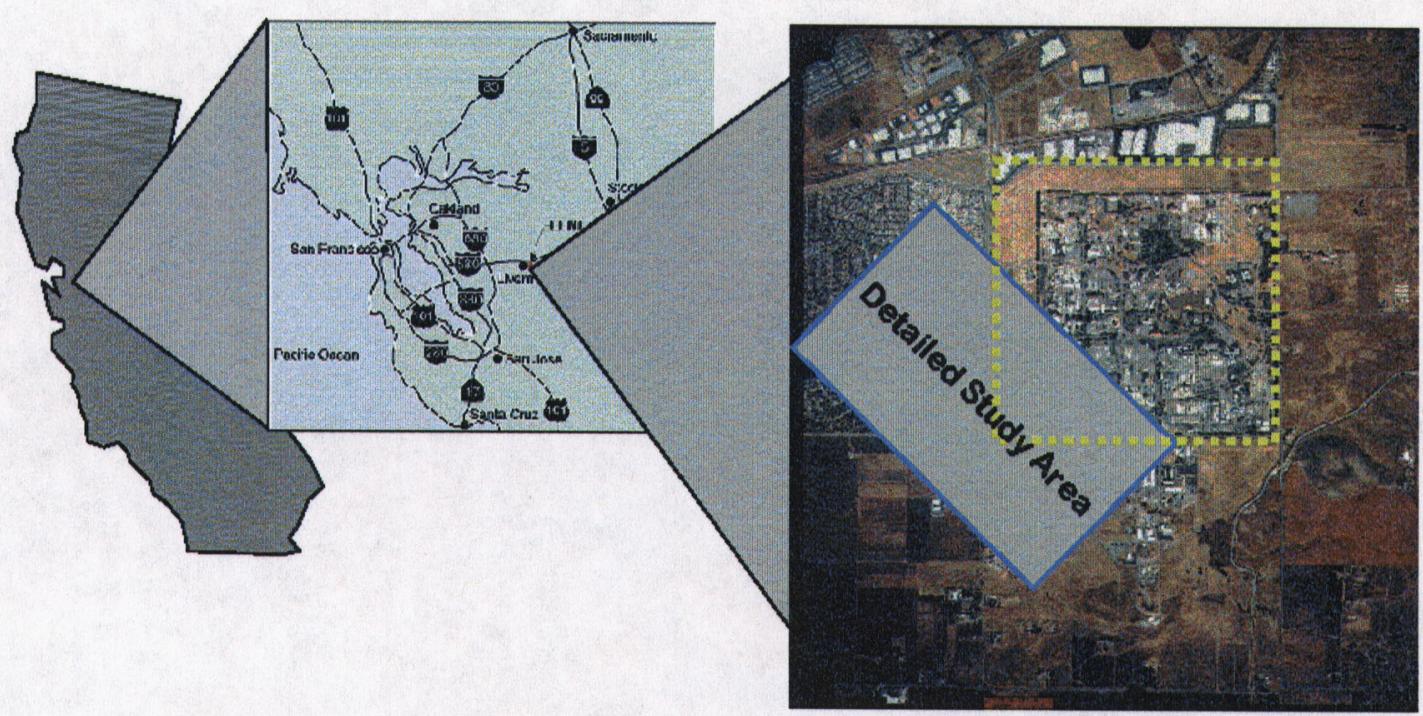

Figure 2. A map denoting the location of the Livermore, and an areal photograph highlighting the detailed study area

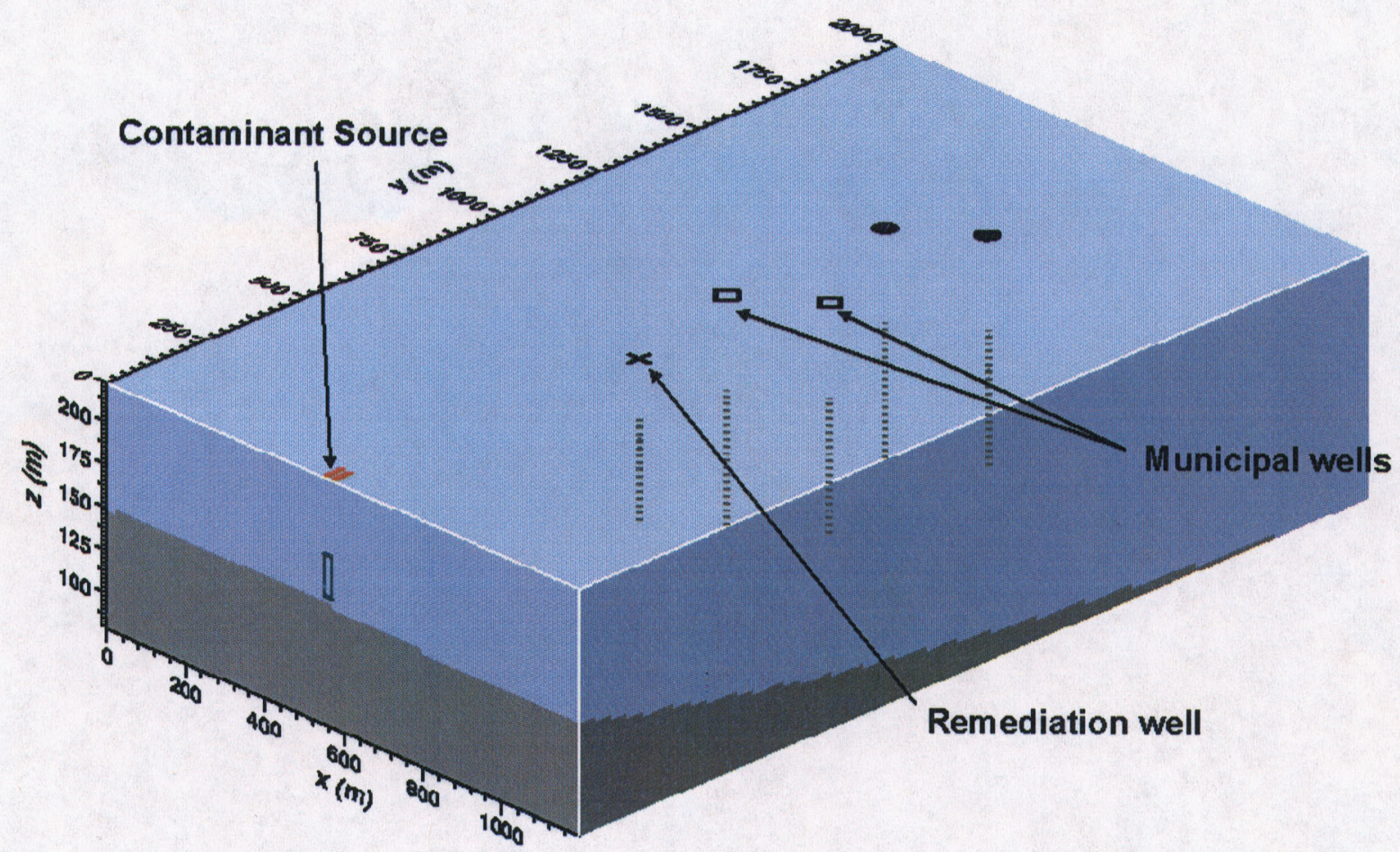

Figure 3. A schematic of the site used in the case study in this paper. The locations municipal wells are shown as dashed lines (denoting the location of the well screen) with diamonds denoting their projection to the top of the domain. The remediation well is similarly depicted, using a cross. The contaminant source location is also shown. 


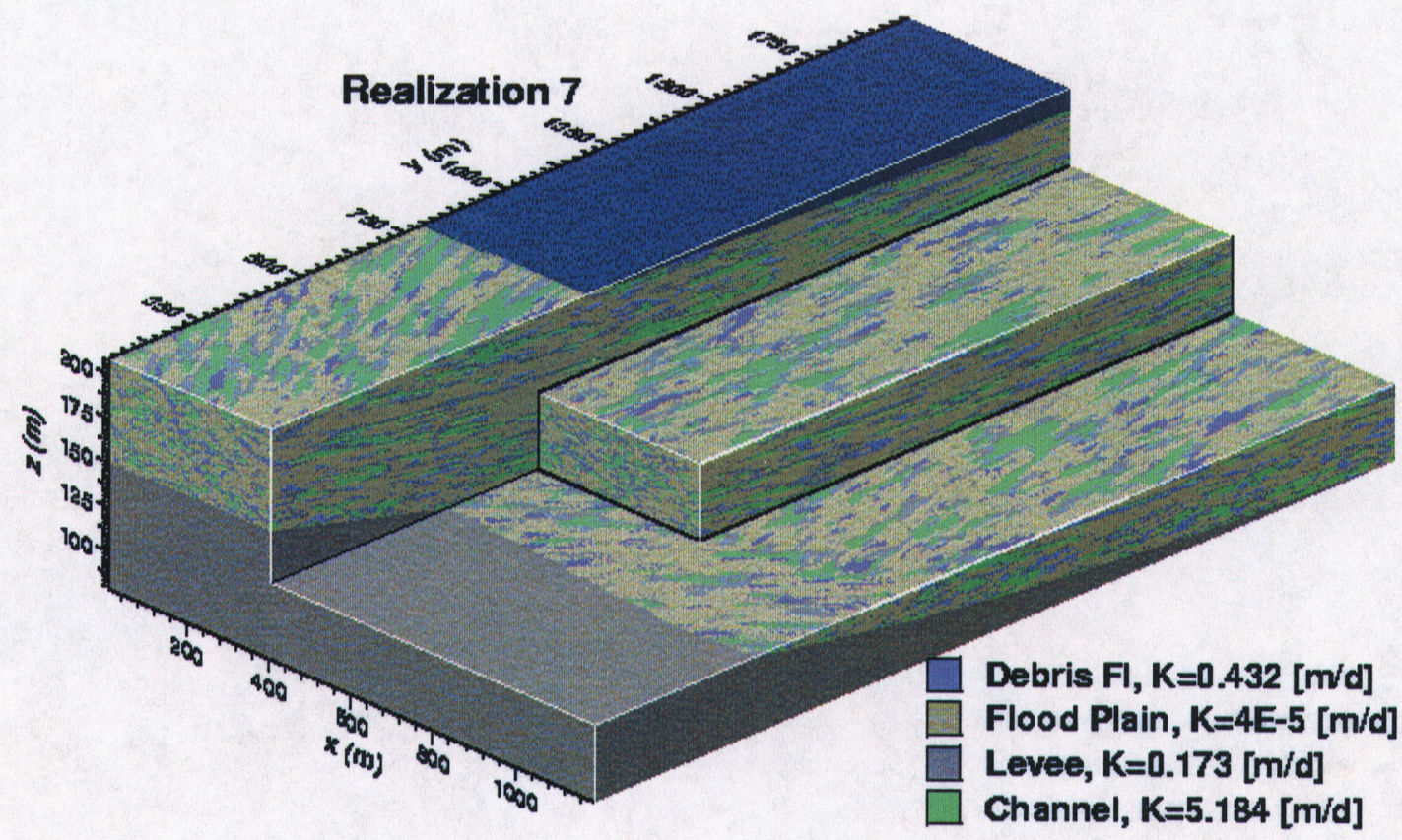

Figure 4. One of the geostatistical realizations of the hydrofacies used to characterize the alluvial system underlying the LLNL site. Corresponding hydraulic conductivity values are also shown.

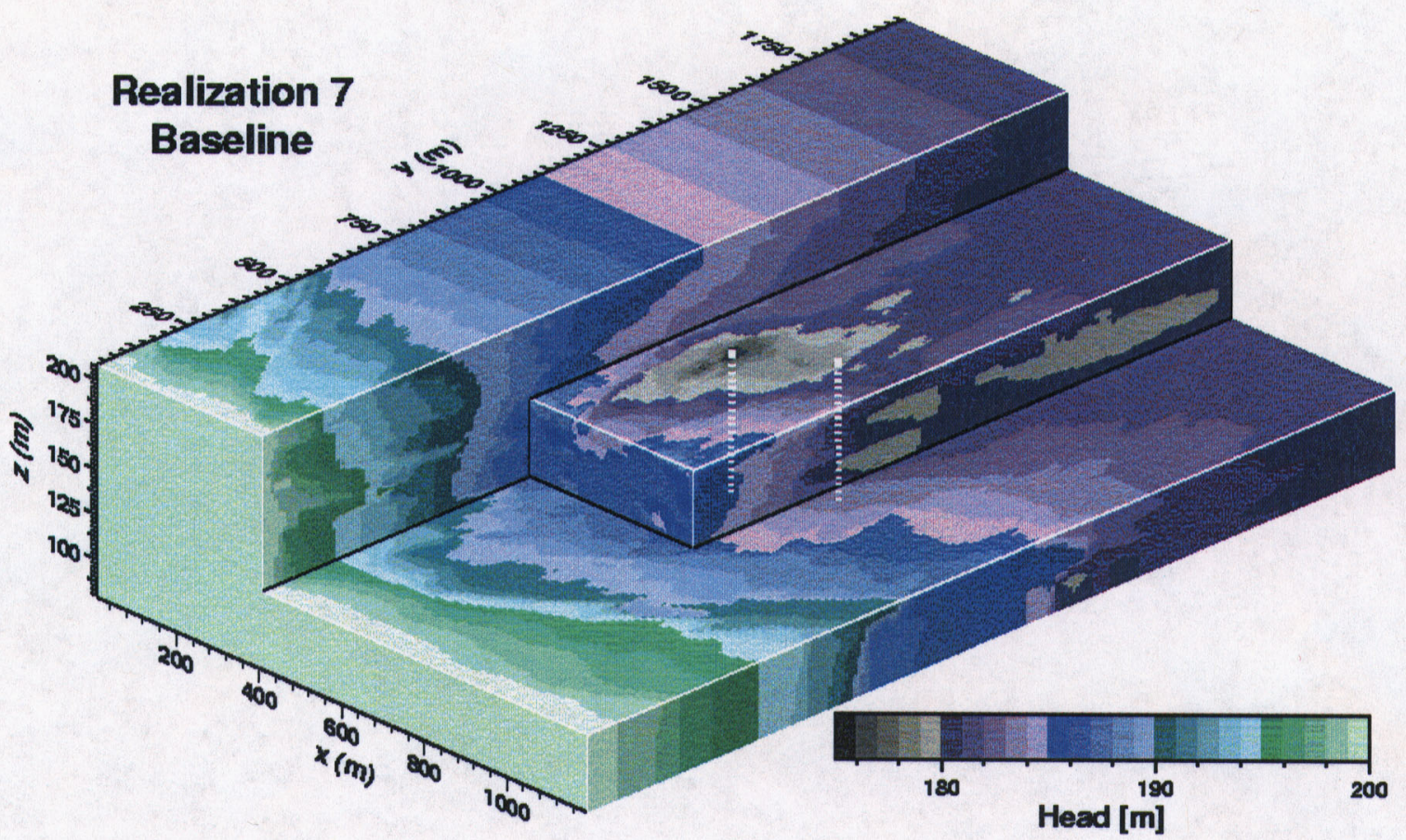

Figure 5. The head solution for the baseline case, for realization seven. The locations of the municipal well screens are shown as dashed lines. 


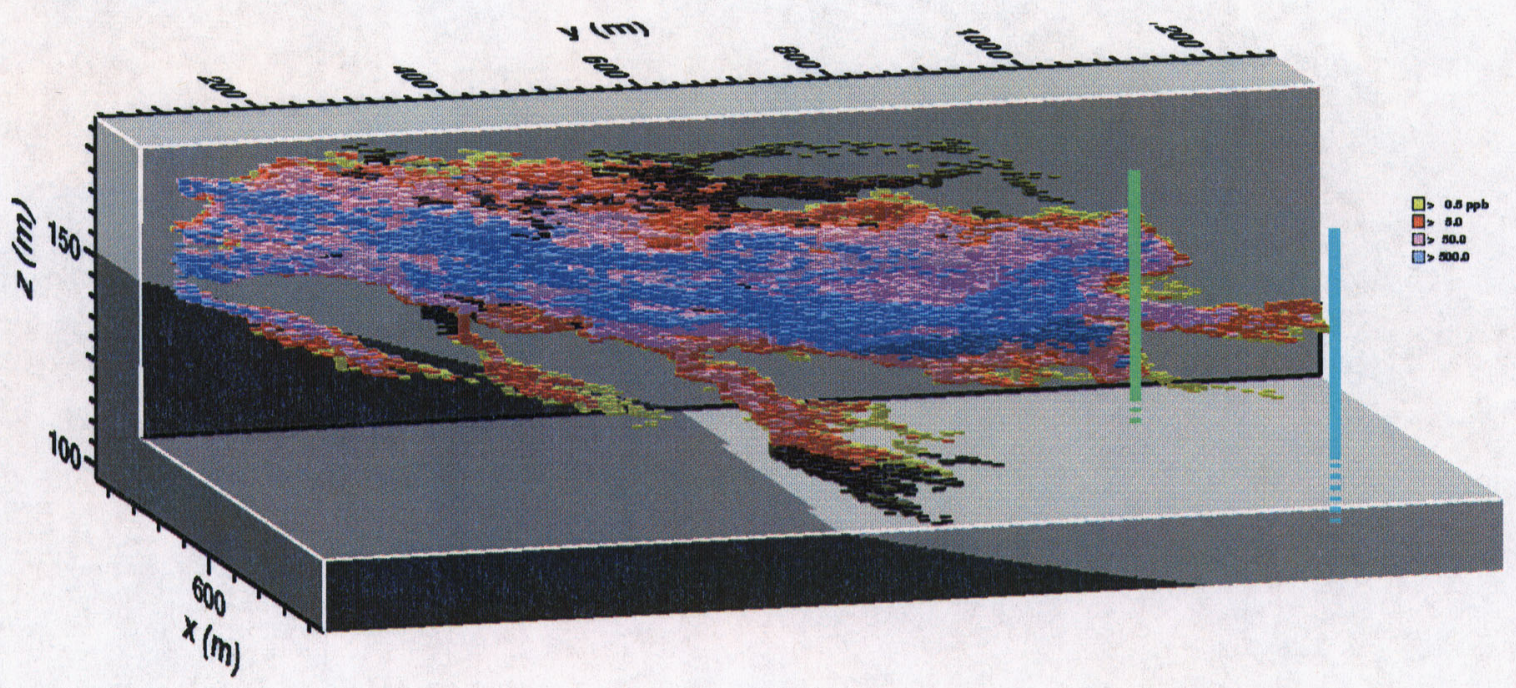

Figure 6. Spatial distribution of PCE after 15 years of migration, realization seven for the baseline (unremediated) case.
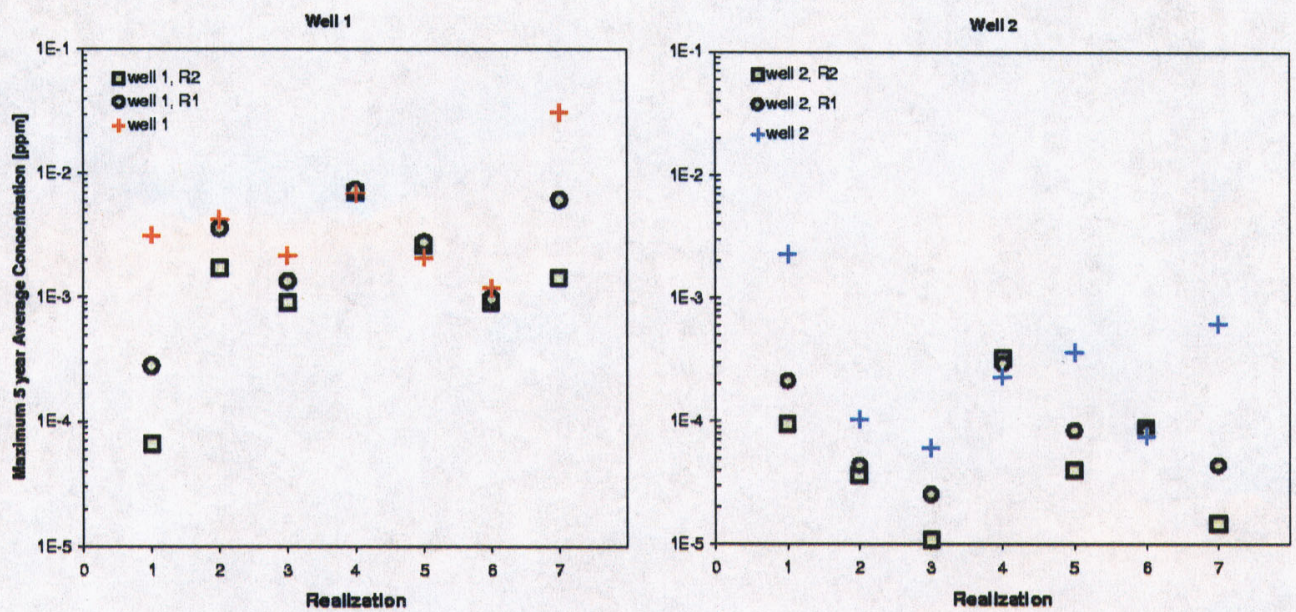

Figure 7. The five-year maximum average concentration for wells one and two, plotted accross the seven realizations of hydraulic conductivity. The pluses indicate concentrations for the baseline (unremediated) case, the circles indicate concentrations for the remediated case at the first pumping rate, the squares indicate concentrations for the remediated case at the second pumping rate. 


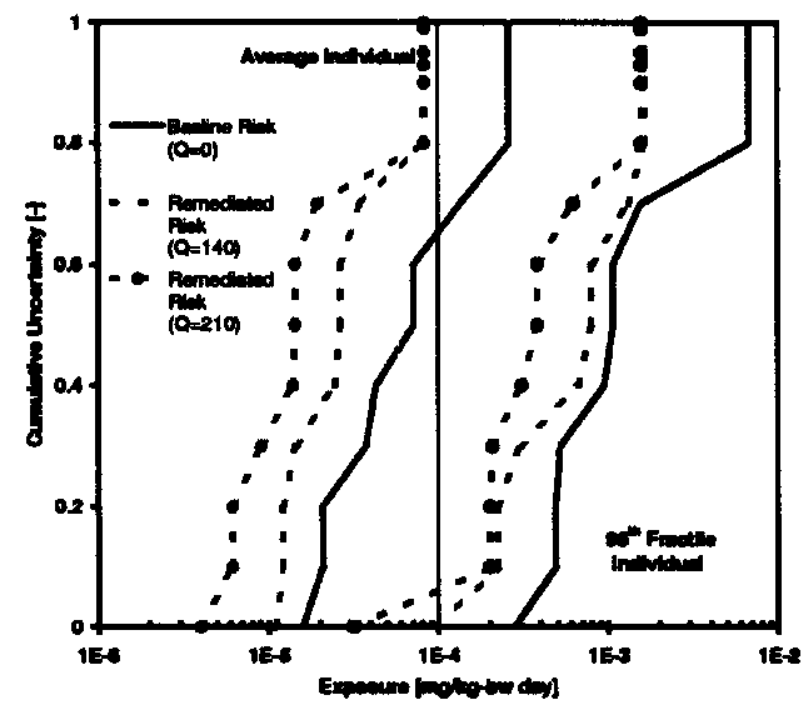

Figure 8. Cumulative distributions of human exposure to PCE for the baseline (unremediated) case and the two remediated cases. The curves to the left of the figure represent an individual at the median level of exposure, the curves to the right of the figure represent an individual at the 95th fractile level of exposure.

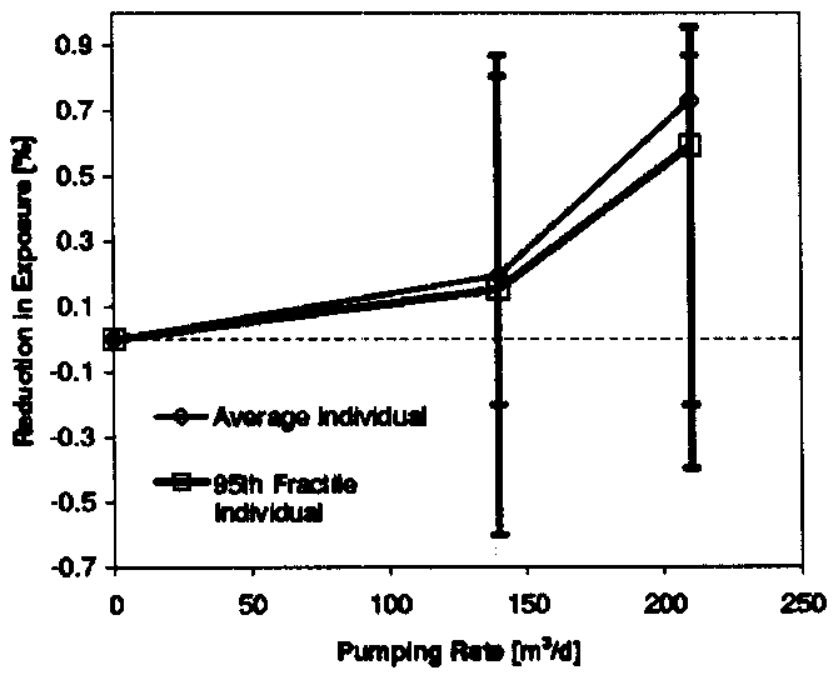

Figure 9. Plot of the percent reduction in exposure as a function of pumping rate of the remediation well. The symbols represent the median (or expected) reduction in exposure to two representative individuals within the exposed population, the error bars denote the lower 10th and upper 90th confidence intervals about this prediction. 